\title{
Vtělení paměti a minulosti do svatojakubské cesty a společensko-vědního diskursu
}

\author{
JAN KaPUSTA*
}

\section{The Embodiment of Memory and Past into the Way of Saint James and Social Science Discourse}

\begin{abstract}
The study has two objectives. Firstly, offering a summary of theory of collective memory, it is argued that the concept of memory tends to be used in a broad sense, threatening to fusion with the anthropological notion of culture. In this respect, it is proposed to use the term when referring to the social remembering of specific historical events, persons and experiences in a particular society or culture at a particular place and time. Moreover, several reasons of the memory boom such as some theoretical problems within the social sciences, the specificity of French culture and historiography, postmodern turn, detraditionalism or discourse of postcolonialism are indicated. The other purpose of the study consists in emphasising of the psychosocial power of the past and socially constructed history in the traditional as well as contemporary pilgrimage to Santiago de Compostela. The disintegration of old myths demands the rise of new chains of memory. Comparing the work of the scholars like Nora and Hervieu-Léger with the ideas of Halbwachs and Eliade, the same power of the past is recognized in some academic and intellectual discourses. The conclusion presents the social and scientific attractiveness of memory as a consequence of the need of identity, significance and sense, and the never-ending debate about change and continuity.
\end{abstract}

Keywords: memory, culture, history, tradition, performance, pilgrimage, Way of Saint James

\section{Úvod}

Zdá se, že čas paměti nadešel už i v naší české kotlině. ${ }^{1} \mathrm{~S}$ každým trendem vzniká mimo jiné otázka, co s sebou daný směr přináší nebo co může přinést; rovněž je dobré tázat se po jeho příčinách a významu.

Od 80. let 20. století dochází v sociálních vědách k módnímu vzepjetí pojmu pamět. Tento zájem se významně dotkl historie, sociologie, antropologie i dalších společenských a humanitních věd. Dříve byla pamět na okraji zájmu [Klein 2000]; dnes má sílu nejen ve vědeckých kruzích, ale i ve společenském a politickém diskursu, kde získává rétorickou moc [Todorov 1995]. Soudobé sociální vědy (a antropologie zvlášt') mají v oblibě paradigmata relativizovat a „dekonstruovat“. Také tato studie se pokouší pohlédnout na současné okouzlení pamětí, pokud možno z nadhledu a zároveň poukázat na možnosti a výzvy, které téma otvírá.

\footnotetext{
* Mgr. Jan Kapusta, Ústav etnologie, Filozofická fakulta Univerzity Karlovy, nám. Jana Palacha 2, 11000 Praha 1. E-mail: kapusta.jan@seznam.cz

1 Abychom nechodili daleko, je možné uvést nedávnou studii Jiřího Šubrta a Štěpánky Pfeiferové, uveřejněnou v Historické sociologii [2010]. Mezi čtyři vybrané přístupy moderní sociologie náboženství zařadil teorii kolektivní paměti Zdeněk Nešpor [2008]; do praxe ji zavádí např. Adela Kvasničková [2005]. Český čtenář se už také může obrátit k „pramenům“, respektive k překladu Kolektivní paměti Maurice Halbwachse [2009 (1950)].
} 
Studie má dvě relativně samostatné části: První část představuje teoretickou diskusi nad pojmem pamět v sociálních vědách, nad jeho původem, vývojem, obsahem a využitím; půjde mimo jiné o to nastínit hlavní př́stupy k tomuto konceptu, vystihnout některé $\mathrm{z}$ kořenů fascinace tímto pojmem a zamyslit se nad jeho užitím, které by se vyvarovalo jeho obsahového přesycení. Druhá část se zaměřuje na jeden významný aspekt paměti, totiž minulost, jež je společností utvářena a která na ni zároveň působí nemalou mocí. Téma nás pak znovu zavede k místu paměti a minulosti v současném světě. Druhá část studie vychází z materiálu antropologie poutnictví, konkrétně cesty do Santiaga de Compostela. Předložená práce se pohybuje v interdisciplinárním prostoru a reaguje na současnou debatu o výzvách a hrozbách opouštění tradice a „ztráty paměti“, reprezentovanou zvláště Pierrem Norou a Danièle Hervieu-Légerovou, pokračujících v odkazu Maurice Halbwachse. Přitom nelze utajit, že je jejím autorem antropolog, který se zamýšlí nad tématem ze svého úhlu pohledu a jenž hledá místo konceptu pamět především v rámci teorie své disciplíny.

\section{Pojetí paměti v sociálních vědách}

Pojem paměti zpravidla označuje dvě věci: schopnost uchovávat vjemy a zkušenosti a vybavovat si je; zároveň ale i tyto uchovávané vjemy a zkušenosti samé. Pamět je schopnost si pamatovat i obsah, který je pamatován. Pamět pak lze studovat z neuropsychologického, nebo psychosociálního hlediska: v prvním případě nás zajímá činnost lidského mozku; v druhém případě činnost člověka ve společnosti. Jak známo, koncept paměti jako sociálního konstruktu uvedl do vědy francouzský sociolog Maurice Halbwachs. Spolu s ním použil pojem „sociální pamět“ také historik umění Aby Warburg, jenž tak odkazoval k hodnotě uměleckých děl jakožto pokladnic historie.

Halbwachsův pojem „kolektivní pamět“ nese inspiraci Durkheimovým „kolektivním vědomím“, které je nepřevoditelné na to individuální, tj. žije si svým vlastním životem. Z tohoto hlediska je pro Halbwachse pamět vždy sociální, at už je kolektivní, nebo individuální [Halbwachs 1992 (1925); 2009 (1950)]. Jednoduše řečeno, to, co a jak si pamatujeme, je výsledkem naší účasti na konkrétních „společnostech“ či „skupinách“. Naše vjemy a vzpomínky filtrujeme skrz koncepty či představy, které nám poskytla naše rodina, škola, církev nebo národ: individuální pamět je utvářena a udržována v tzv. „sociálních rámcích“. To, co se nám jeví jako jedinečná osobní vzpomínka, je výsledkem vlivu celého souboru různých „proudů myšlení“, s nimiž jsme přišli do styku: naše vzpomínka je proto vždy nějak sociální. „Není individuální paměti bez sociální zkušenosti, ani kolektivní paměti bez individuí participujících na společenském životě [Olick 1999: 346]. “ Pamět je vlastně průsečíkem mezi individuálním a kolektivním a mezi minulostí a prítomností.

Halbwachs se zabýval pluralitou kolektivních pamětí (rodinnou, třídní, náboženskou apod.), ale také komplexitou lidského vědomí, které z těchto pamětí ukrajuje jen určité části. ${ }^{2}$ Pamatujeme si to, co je z minulosti nějak aktuální i v současnosti, co pro nás má význam. Vše podléhá selekci a interpretaci. Kolektivní pamět je živými dějinami, pocitovanými jako smysluplné kontinuum. Pamět je pro Halbwachse minulost v př́tomnosti.

2 „Bez problémů můžeme připustit, že každá individuální pamět představuje způsob vidění kolektivní paměti a že tento zposob se mění v závislosti na místě, které zaujímáme, a zároveň že toto místo se mění podle vztahů, které udržuji s ostatními prostředími [Halbwachs 2009 (1950): 91].“ 
Jak ale správně ř́ká editor jeho díla Gérard Namer, význam této definice lze číst jinak v Sociálních rámcích paměti (1925) a jinak v Kolektivní paměti (1950). V první práci sledujeme skupiny a jednotlivce svrchu, a jako nezávislí pozorovatelé tak vidíme, že pamět je minulost rekonstruovaná podle představ a potřeb přítomnosti; pozorujeme ji ve změně. Ve druhé práci sledujeme skupiny a jednotlivce naopak zdola, jejich vlastníma očima, a vidíme pamět jako minulost, neměnně přetrvávající v př́tomnosti; pozorujeme ji v kontinuitě [Namer 2009 (1997)]. Udržovat vzpomínky na minulost pomáhají paměti vyprávění, texty, předměty, stavby, místa, ale především rituály, které minulost nejen připomínají, ale i oživují, reprodukují. Jsou oporami paměti, spolupracujícími na stabilizaci a kontinuitě skupin a společnosti.

Přes nevyhnutelné zjednodušení je na tomto místě zapotřebí zmínit ještě práce několika dalších autorů. Koncept kolektivní paměti je zvláště ve Francii blízký sociální historii, kterou od svého počátku pěstovala škola Annales, mezi jejíž zakladatele patřili Lucien Febvre a Marc Bloch. Halbwachs s ní spolupracoval a ostatně i Bloch ve svém díle pojem kolektivní pamět užívá [Bloch 1939-1940]. O popularizaci konceptu na poli historie se však asi nejvíce zasloužili Jan Assmann a Pierre Nora. V rámci své práce v oblasti kulturních dějin starověkých civilizací se německý egyptolog Assmann uchyluje právě k pojmu pamět. Rozlišuje pamět „komunikační“ a „kulturní“. Ta první je dána každodenní komunikací mezi lidmi, vychází z všedního života; je nestálá a krátkodobá. Ta druhá je objektivizovanou kulturou, zahrnující stavby, objekty, obrazy, texty, rituály, tedy vše, co sjednocuje a stabilizuje společnost a dodává jí specifičnost a identitu; je stálá a dlouhodobá [Assmann 1995]. Francouzský historik Nora se zaměřuje na „národní pamět“ v moderní době. Ve svém obrovském projektu Místa paměti představuje oblasti či věci, v nichž je „kondenzována“ francouzská národní pamět, at jsou to stavby, monumenty, pomníky, výtvarná či hudební díla, texty, rituály a svátky anebo ještě méně hmatatelné symboly typu trikolóry nebo hesla „svoboda, rovnost, bratrství“. Toto všechno jsou pro Noru „lieux de mémoire“, tedy jakási „místa“ či „oblasti“ paměti, která mají sociálně identifikační moc, jsou to odkazy k národním dějinám a symboly francouzství [Nora 1984-1992].

V antropologii byli průkopníky studia paměti Roger Bastide a Jack Goody. Francouzský sociolog a antropolog Bastide, jenž je znám svými výzkumy afroamerické kultury v Brazílii, kladl při studiu rituálu důraz na kolektivní pamět, která je skrze něj přehrávána, pozměňována a uchovávána. Původem africké rituály z konkrétních míst černého kontinentu jsou reaktualizovány na půdě Nového světa, čímž je zajištěna kulturní kontinuita [Bastide 1970]. Goody, významný britský antropolog, pracoval s pojmem pamět ještě specifičtěji: zajímal ho v první řadě proces, jak a proč si lidé něco pamatují, proces učení a předávání určitých kulturních prvků. Na africkém materiálu se zabýval vyprávěním a předáváním mýtu, tím, jak se mýtus každou prezentací mění. Vyprávění - a v důsledku předávání kultury obecně - je podle něho vždy tvořivou rekonstrukcí [Goody 1972]. Později se zaměřil na problematiku ústně a písemně předávaného vědění, respektive na to, jaký dopad na myšlení a pamět má přechod od jednoho typu k druhému [Goody 1977].

Ačkoliv termín „ústní tradice“ belgického historika a antropologa Jana Vansiny dosáhl jisté proslulosti [Vansina 1985], má v antropologii daleko větší dopad pojetí paměti britského sociologa a antropologa Paula Connertona. Ten rozvíjí s odvoláním 
na Halbwachse teorii „sociální paměti“, chápané v nejširším slova smyslu jako vše, co spojuje minulost s přítomností, jako dědictví předávané z generace na generaci, kulturní přenos a přetrvávání. Rozlišuje „osobní pamět“ týkající se životního př́běhu individua, dále „kognitivní pamět“ zahrnující společenské představy a pravidla, tedy veškeré vědění nezbytné k orientaci ve světě a společnosti, konečně pak „zvykovou pamět“ odkazující k tělesným praktikám, sociálně rozpoznatelným a významuplným zpơsobům komunikace tělem, od oblečení a úpravy těla po pohyby, gesta, mimiku, zvuky atd. Connerton se ptá, jak je sociální pamět přenášena a udržována, a odpovídá, že „připomínkovými ceremoniemi“ a „tělesnými praktikami“ či „představeními“. Na rituálu ho nejvíce zajímají jeho forma (tj. jeho konkrétní provozování prostřednictvím lidského těla) a úkol přehrávání prototypických vzorů. Rituál je v první řadě performance a bez ní rituálem není. Minulost je předávána jejím přehráváním a znovuzažíváním; tělesná akce znovuožívá zase jen v tělesné akci. Tělo pomáhá paměti, ale také je pamětí: její obsahy jsou do něho „vtěleny“ [Connerton 1989].

\section{Pamět, anebo kultura?}

Při četbě Halbwachse, Connertona, Assmanna nebo Nory se však neodbytně navrací jedna otázka: není to, co mají tito autoři na mysli a co nazývají pamětí, ve skutečnosti to, pro co je zaveden pojem kultura? A pokud ano, co to pro tyto koncepty znamená?

Vrat̉me se k Halbwachsovi. Jak píše Namer, sám Halbwachs postupně přešel od kolektivní paměti, jejímž obsahem byly dějiny založené na společných vzpomínkách na události, postavy a zkušenosti, k paměti založené na hodnotách a vědění. „V Sociálních rámcích se jednalo o pamět faktů, v Kolektivní paměti jde o pamět kultury, tj. o pamět hodnot. A to o pamět takových hodnot, které nám umožňují mít v sobě ,celý svět paměti‘, abychom užili jedné z variant Halbwachsových výrazů [Namer 2009 (1997): 250-251]. “ Že měl nakonec Halbwachs na mysli skutečně to, co dnes nazýváme kulturou, je zřejmé již z jeho stati o „kolektivní paměti hudebníků“ z roku 1939, kde pamět chápe jako „svět“ nebo „proud myšlení“, který zahrnuje společné dějiny, představy, obrazy a hodnoty. Na př́kladu ohluchlého a osamoceného Beethovena ukazuje, že tehdy „Beethoven nebyl sám“, nýbrž byl ve „světě hudebníků“, který si přinesl ze své zkušenosti s nimi a jenž nadále utvářel [Halbwachs 2009 (1950): 42]. Člověk může myslet a vzpomínat jen v rámci těchto „světů“, kolektivních pamětí, a at̉ už určitá vzpomínka referuje k události či věci prožité o samotě, anebo ve společnosti, vždy je v důsledku kolektivní, protože „ve skutečnosti nikdy nejsme sami“ [tamtéž: 51].

Halbwachs v meziválečné době vyvinul svébytný koncept kultury uchopené v kontextu pamětového procesu. Jeho pojem kolektivní pamět vystihuje obsah toho, co ve stejné době antropologové (především ve Spojených státech amerických) promýšleli pod označením kultura, pod pojmem, který nebýval v tehdejší Francii takto užíván. Nicméně dnešní Halbwachsovi pokračovatelé nenásledují svého mistra jen v jeho myšlenkách, nýbrž i v jeho pojmosloví; výsledkem pak je, že pojmy pamět, tradice a kultura splývají v jeden nejasný konglomerát. Toho, že se pojem pamět začíná užívat v př́liš obecných a nejasných významech, si povšimli jak sociologové [Olick - Robbins 1998], tak historici [Kansteiner 2002]. ${ }^{3}$ Pokud začneme chápat kolektivní pamět jednoduše jako

3 Obě citované práce jsou navíc obsáhlým úvodem do dějin, metodologie a teorie paměti v sociálních vědách. 
minulost v přítomnosti, jako vše, co a jak si pamatujeme, zahrneme tak do ní v podstatě všechny lidské kognitivní výtvory, splyne nám se zavedenými koncepty typu vědění a kultury (např. u Assmanna nebo Connertona) anebo etnicity či národní identity (jako u Nory). Podobně věc vidí třeba Noa Gedi a Yigal Elam, pro něž je pamět náhradou starších pojmů specifičtějších významů, především mýtu. Nejrozumnější by bylo tuto módní náhražku opustit [Gedi - Elam 1996].

Problém se týká zvláště antropologie, jejíž „živností“ kultura a tradice jsou. Vzpomeneme-li na Noru, jenž hledá pamět v názvech ulic, v Dnu Bastily, v Janě z Arku, v národní gastronomii či v jazyce, nabízí se otázka, co potom není věc paměti? Assmann definuje kulturní pamět jako „veškeré vědění, které řídí chování a prožívání v interaktivním rámci společnosti a které prochází generacemi opakováním sociální praxe a iniciace“ [Assmann 1995: 126]. Tato definice se prakticky nijak neliší od antropologických definic kultury, které zpravidla odkazují k představám, vzorcům chování a hodnotám, předávaným z generace na generaci prostřednictvím symbolů a jejich vtělení do materiálního světa, do artefaktů. Kultura je historický produkt, podléhající neustálé selekci a interpretaci. Zahrnuje jak obsah (konkrétní představy, praktiky, artefakty), tak proces, jímž je tento obsah předáván, zachováván či měněn.

Některé definice kolektivní, sociální či kulturní paměti jsou tak široké, že nelze určit, co do ní vlastně nepatř́í, vlastně jaký je rozdíl mezi pamětí a kulturou. Tento epistemologický problém vede některé autory k závěru, že je pojem pamět neúčelně sémanticky rozššřen, obtěžkán či přesycen, jednoduše řečeno, je nadužíván a nadhodnocen. Jeho vágnost pak vede k terminologickému zmatení, a to zvláště v antropologii, kde je napaden samotný její projekt, tedy koncept kultury [Berliner 2005]. To vede ke dvěma klíčovým otázkám: za prvé, proč k takové fascinaci pamětí a jejímu následnému významovému rozředění došlo; za druhé, co přesně je pojmem pamět v současné antropologii označováno, potažmo co by jím označováno být mohlo.

\section{Dekonstrukce paměti}

Při hledání kořenů současné fascinace pamětí se zaměřím na tři oblasti: na roli paměti v současné společnosti obecně, na význam paměti v rámci francouzského dějepisectví a kultury a na místo paměti v antropologické teorii.

Není těžké vytušit, že boom studií kolektivní paměti souvisí se společenským a kulturním děním obecně. Vědecká témata často reagují na nálady společnosti. Postmoderní obrat sahá v uměleckých a filosofických kruzích hluboko do 20. století, společnost jako celek ale zasáhl až od 80 . let. Je to právě postmoderní situace, která radikálně zrelativizovala a zpochybnila „velká vyprávění“, mýty, tradici, tedy „kolektivní pamět“. Tradice se stala nedostatkovým zbožím, a tak i objektem nostalgie a touhy. Kořeny jsou zpřetrhávány a jistoty mizí. Jak ř́ká francouzský antropolog Joël Candau, jde o identitu: právě tradice a pamět jsou zásadními kameny identit; naše společnost odmítá tradici, nechce či neumí ji předávat, a tím více je jí fascinována [Candau 1998].

Ostatně problém rozeznává sám Nora: „Tolik mluvíme o paměti, protože nám mizí před očima [Nora 1989: 7]. “ Současný člověk přerušil svůj žitý, spontánní kontakt s mytickou minulostí, uvádí Nora. Současná vědecká historie už neposkytuje koherentní obraz světa, světa hodnotově zatíženého, významově nabitého a smysluplného. Opouštění jistot, tradice a zvyku vede k nostalgii a k obracení pozornosti k místům paměti, 
která nás na minulost uměle navazují: „Kdybychom byli schopni žít s pamětí, nepotřebovali bychom „zposvátňovat lieux de mémoire“ [tamtéž: 8]. Podobně uvažuje známá francouzská socioložka Danièle Hervieu-Légerová, jež v udržování „řetězce tradice“ spatřuje samou sociologickou podstatu náboženství; současnou krizi víry a identity vidí právě ve ztrátě kolektivní paměti [Hervieu-Léger 2000 (1993)].

Francouzské zaujetí pamětí je výrazné: Halbwachs, Bastide, Nora, Hervieu-Légerová - ti všichni vyrostli v kultuře, jejíž výraznou ikonou je Proustovo Hledání ztraceného času. Někteří z francouzských historiků dali před „historickými fakty“ přednost historii „dlouhého trvání“, „historické antropologii“, „studiu mentalit“, „ústním dějinám“, rekonstrukci lidové paměti. Ve Francii se také rozvíjela kritická historiografie oboru, tedy „historie historie“, pro niž jsou dějiny vždy situované a sociálně konstruované. Podle Jacquesa Le Goffa historik kombinuje vyprávění a výklad dějin a vytváři „Zvláštní literární žánr, který je vědou a uměním zároveň“ [Le Goff 2007 (1986): 17]. Jak dodává Peter Burke, vědění bylo vždy dobově podmíněné [Burke 2007 (2000)], jak uzavírá na jiném místě, „ani pamět ani historie se už nezdají být objektivní. V obou př́padech musíme vzít do úvahy vědomou nebo nevědomou selekci, interpretaci a distorzi. V obou případech je tato selekce, interpretace a distorze sociálně podmíněná“ [Burke 1989: 98].

Kromě specificky pěstované historie přeje francouzskému zájmu o pamět také výrazné vlastenectví. Jak Norův historický projekt národní paměti, tak sociologická teze Hervieu-Légerové reagují na ztrátu historického a národního povědomí a zakotvení dnešních Francouzů. „Ztráta žité paměti“ (Nora) a „přetržení řetězce paměti“ (Hervieu-Légerová) mohou odkazovat také k nostalgii po dobách vrcholné slávy Francie, s jejímž upadáním se francouzské sebevědomí nehodlá smírit. Oživování paměti pak souvisí s hledáním kořenů, identity a jednotného silného národa. Téma je společensky a politicky mocné: $\mathrm{V}$ čem tkví jedinečnost národů a etnik? Na jakých základech budovat jejich identity? Kolektivní pamět je tak vděčnou látkou ke studiu.

Nicméně v této studii mě zajímá především místo konceptu paměti v antropologii. Také v ní hrají svou roli výše popsané skutečnosti; chtěl bych však poukázat ještě na dva další aspekty věci - na diskusi o kontinuitě a na problém postkolonialismu. Na otázku, v čem spočívá dnešní popularita paměti v antropologii, odpovídá belgický antropolog David Berliner, že v její „konceptuální účinnosti navázat na antropologický projekt porozumění kontinuitě“ [Berliner 2005: 205]. Jedná se podle něho o „převtělení nikdy nekončící debaty o kontinuitě a reprodukci společnosti“ a dodává: „Uvědomuji si, že konceptuální interference mezi pamětí a kulturou nám do velké míry ukazují, jakým způsobem antropologové konceptualizují společnost a kulturu [tamtéž: 203]“. Od studia „přežitků“ evolucionistů Tylora nebo Frazera až po současnou kognitivní antropologii Blocha a Whitehouse jde o jedno velké téma - porozumět přenosu kultury, kulturní kontinuitě, kulturnímu procesu. ${ }^{4}$ Toto antropologické téma par excellence

4 Problematika se také dotýká zásadního metodologického sporu synchronního a asynchronního přístupu ke kultuře. Koncept kolektivní paměti dovoluje z určitého hlediska smířit klasický strnulý západoevropský funkcionalismus, který kulturní změnu př́liš netematizuje, a historický severoamerický kulturalismus, jenž klade důraz na kontext a změnu. Pojem kolektivní paměti zdůrazňuje kontinuitu, přetrvávání a stabilitu, zároveň ale i neustálý vývoj, změnu a dynamiku. Tento postřeh do jisté míry rezonuje s pokusem Hervieu-Légerové překlenout spor o funkcionální/substancionální podstatu náboženství a sekularizace. 
se dostalo do obecně společenskovědního diskursu, interdisciplinárního prostředí a širšího kontextu. ${ }^{5}$

Je ale ještě jedna oblast zájmu, která dodává kolektivní paměti v rámci současné antropologie mízu, totiž neméně módní diskurs postkolonialismu, tak typický pro postmoderní Francii a USA. Snaha podívat se na věci „očima těch druhých“, těch porobených a vykořistovaných, je na americkém materiálu dobře patrná: potřeba vyrovnání se s dědictvím likvidace indiánských a afrických kultur vede k rozmachu etnohistorie, na které spolupracují historici, antropologové i archeologové. Kolektivní pamět nehledají jen indiáni na svých tradičních teritoriích nebo v muzeích, na kterých žádají kultovní předměty či samotné ostatky svých předků, ale i Afroameričané, navracející se na místa „obtěžkaná pamětí“ na americké i africké půdě. Můžeme však přejít také na obecnější rovinu: kolektivní pamět je studována v souvislosti s traumatickými historickými zkušenostmi různých vykořeněných a marginalizovaných kultur a etnických menšin, postižených západním kolonialismem nebo imperialismem. A ještě dál: jako trauma lze nahlédnout i postmoderní situaci Západu samotného. Detradicionalizace a sekularizace Evropy, které vedou ke ztrátě kontinuity, jistot a identit, jsou problémem, o němž tak zaníceně hovoří Nora či Hervieu-Légerová.

Mnozí by jistě mohli argumentovat, že je okouzlení pamětí podlehnutím módě a společenským a akademickým trendům, že jde o rétorickou figuru, která přitahuje pozornost. Saháme po paměti ve chvíli, kdy zní pojem mýtus pejorativně a primitivisticky, pojem tradice zastarale a rigidně a kultura př́liš rozbředle a zprofanovaně. To vše je zčásti pravda. Na tomto místě jsem se snažil ukázat, že módnost konceptu kolektivní paměti souvisí také s teoretickými a metodologickými tématy sociálních věd, ale především s postmoderní situací, detradicionalizací a postkolonialismem, které otevírají všestranně společensky aktuální a ožehavé otázky po zásadních (a často traumatických) historických událostech a zkušenostech problematizujících identitu.

\section{Rekonstrukce paměti}

Po „dekonstrukci“ soudobého užití pojmu kolektivní pamět se patří podat také jeho „rekonstrukci“. Antropologie paměti se zpravidla zabývá tím, jak jsou dějiny žity, přičemž zdůrazňuje, že se pojetí a prožívání totožných událostí liší nejen mezi jednotlivými etniky nebo skupinami, ale i mezi jejich členy. Antropologa zajímá, jak se vytvářejí, sdílejí a předávají vzpomínky $\mathrm{v}$ různých kulturách $\mathrm{v}$ časoprostorovém kontextu. Paměti pomáhají místa, předměty či zobrazení, které „materializuji““ sdílené dějiny [např. Küchler 1988], či lidské tělo [např. Stoller 1994]. Pamět na historická traumata oživují vyprávění a rituály, navozující kontinuitu tu se zotročenými předky a Afrikou [např. Ebron 1998], tu s nositeli staré indiánské tradice a identity [např. Beisaw 2010].

Le Goff konstatuje, že v historii už pojem pamět neodkazuje k ústním dějinám či etnohistorii (tj. k tomu, jak sami lidé, skupiny, etnika, národy pojímají svou historii) jako dřív, ale k „dlouhému trvání“ a studiu mentalit [Le Goff 2007 (1986): 108]. Podobně Berliner píše, že zatímco většina antropologů užívá pojmu pamět v odkazu na „sociální vzpomínání na konkrétní historické (a často traumatické) události a zkušenosti“,

5 Velký vliv na zájem o tvorbu kultury a vědění v sociologii a dalších disciplínách měla i „sociologie vědění“ Petera Bergera a Thomase Luckmanna [2011 (1966)]. 
začínají ho mnozí čtenáři Halbwachse, Nory, Connertona či Bastida chápat prostě jako přetrvávání minulosti v přítomnosti; užití pojmu tak v antropologii lavíruje mezi „historií, jak je lidmi žita, a kontinuitou kultury“ [Berliner 2005: 200-201]. Nabízí se potom otázka, zda se nevrátit ke klasickému užití, k němuž odkazují Le Goff a Berliner. Bud’ totiž po obsahové stránce pojem kolektivní paměti redukujeme na vzpomínané historické události, osoby a zkušenosti, a může se z něho stát užitečný nástroj, nebo ho ztotožníme se symboly, mentalitou, jednoduše řečeno s kulturou, a pak pozbývá smyslu. Mluvíme-li o „historických událostech“, je třeba zdůraznit, že nás zajímají nativní pojetí dějin, kde bývá historicita chápána různě a kde je bezpředmětné rozlišovat „reálné“ a „fiktivní“. Samotným pojmem „historie“ podsouváme jiným kulturám západní lineární a kauzalistní pojetí dějin, které vůbec není samozřejmé.

Některé autory zajímá především pamět jako schopnost: Le Goff (podobně jako Goody) chápe pamět jako proces zapamatovávání, uchovávání a zapomínání informací [Le Goff 2007 (1986): 68-112]; Berliner se táže, nemá-li se snad antropologie paměti znovu týkat „porozumění způsobu, jakým lidé vzpomínají a zapomínají na svou minulost“ [Berliner 2005: 206]. V podobných intencích uvažuje i americký sociolog a znalec teorie paměti Jeffrey Olick: „Studia sociální paměti“ by měla zkoumat „způsoby organizace pamatování“, tedy širokou paletu pamětových procesů, praktik a výsledků na kognitivní, individuální i kolektivní rovině [Olick 1999: 346]. Zajímají nás potom způsoby a mechanismy toho, jak jsou historické a kulturní prvky předávány, jakási média paměti, věci (vyprávění, texty, rituály, tělo, zobrazení, místa apod.), které materializují to, co má být pamatováno.

Úkolem filosofie a zároveň i vědy je mimo jiné tvorba pojmů, jimiž uchopujeme svět. Snažil jsem se nastínit možná sémantická pole pojmu (kolektivní či sociální) pamět. Šŕřka a multidimenzionalita konceptu vede mnohé autory k reflexi a snaze nalézt jeho jasnější a specifičtější kontury. Někteří navrhli ho dokonce opustit. Opravdu máme pamět hodit přes palubu, jak naznačují Gedi a Elam? Rozhodně ne. Máme vícero možností, jak se pojmu pamět zhostit. Pamět jako obsah můžeme redukovat na etnohistorii, na sociálně a kulturně zakotvené vzpomínky na minulé události, osoby a zkušenosti; pamět jako schopnost může odkazovat na způsob, jak lidé na svoji minulost vzpomínají a reinterpretují ji, na opory paměti (jako schopnosti), nikoli nositele paměti (jako obsahu). Pamět nemusí splynout s kulturou, ani s kulturním procesem: odkazuje k událostem, které se staly v rámci nějaké kultury, a k prostředkům upomínání na ně. Mưže nás např́iklad jako Halbwachse zajímat, jak jsou žity dějiny křestanství, a také to, jak třeba ústně předávané legendy, kostelní malby nebo poutní rituály představují, připomínají a zpřítomňují historicko-mytické události lidem, kteří se o nich neměli možnost dočíst. Ovšem ani to, že někteří autoři pojmu užívají v širším nebo jiném smyslu (jak uvidíme dále), nemusí být nutně na škodu. Podstatné je, zda jejich přístup nasvěcuje zkoumaný problém z jiného úhlu, zda otevírá nové pohledy a cesty - řečeno jednoduše, zda přispívá poznání. Pamět je předpokladem kultury a kulturní kontinuity a hranice mezi pamětovým a kulturním procesem jsou nejisté, vlastně oba procesy kráčejí ruku v ruce.

\section{Minulost: Hodnocení času a hrůza $\mathrm{z}$ dějin}

Kniha Maurice Halbwachse Sociální rámce paměti není jen knihou o společensky utvářené paměti, ale také o místu, významu a síle minulosti v lidském myšlení. V této části 
studie se zaměřím právě na toto téma. Pomohu si příkladem křestanského poutnictví, konkrétně poutí do Santiaga de Compostela. Tento exkurs bude bohužel značně omezený, reaguje čistě na naše téma významu minulosti. Budu-li hovořit o kolektivní paměti, bude se týkat nativních dějin, tj. sociálně konstruovaného obrazu minulých údobí, událostí a osob v určité společnosti či skupině v daném prostoru a čase. V obecnějších úvahách se nicméně budu snažit nezkreslit pohled citovaných autorů, kteří v návaznosti na Halbwachse užívají pojmu v širším slova smyslu. Nejdříve je však zapotřebí stručně se pozastavit u evropského chápání dějin a minulosti obecně.

Také vnímání času je do určité míry kulturně konstruované. Čas můžeme chápat cyklicky nebo lineárně: ačkoliv je křestanské pojetí času a dějin založeno na jejich linearitě, pracuje hojně i s obřadními cykly a opakováními. Dějiny jsou navíc hodnotící. Pro většinu kultur (z jisté části také pro tu křestanskou) jsou dějiny regresívní. Vzhlíží se do minulosti, kde je hledán „zlatý věk“, věk počátků a předků; současnost je považována za krizi, znamení úpadku. Daleko výjimečnější je pojetí progresívní, typické zvláště pro západní kulturu zhruba od poloviny 19. do poloviny 20. století: to minulé je označeno za zaostalé a překonané, bránící pokroku. Dějiny nejsou hodnoceny jen dle svého celkového směřování, ale také dle svých údobí. Například evropská civilizace nevzpomínala jen na biblické události, nýbrž třeba i na svou antickou minulost. Češi ještě donedávna spatřovali svůj zlatý věk v době husitství, nověji toto období hodnotí (v protikladu k baroku) jako barbarské. Pohledy a preference se mění, historické se prolíná s mytickým; každá takováto kulturní klasifikace dějin však leží v základech identit.

Jakkoliv bylo osvícenství prostoupeno historickým optimismem a vizemi upřenými do budoucnosti, navrátil se romantismus ke glorifikaci starého, původního, mytického. V průběhu 19. století však postupně vítězí idea pokroku: bezprecedentní vědecký a technologický rozvoj a ideologie pozitivismu a evolucionismu vedou k zavržení minulosti jakožto zpátečnictví a primitivismu. Skrytý chiliasmus nelze upř́í mnohým politickým ideologiím usilujícím o stržení nebe na zem (komunismu a fašismu) nebo těm ekonomickým (kapitalismu a ideji neomezeného ekonomického růstu). Jak poznamenává Hervieu-Légerová, modernita byla postavena na ruinách náboženství: také sekulární dějiny totiž spějí ke Království, totiž k Pokroku [Hervieu-Léger 1990: 22]. Modernita ale znala i kolektivní pamět, podle Nory přítomnou v ideji Národa, jíž podporovaly dějiny, muzea, památníky apod. [Nora 1989: 11]. Progresismus a nacionalismus mají společné to, že ustavují místo člověka v dějinách, dějiny vysvětlují a dávají jim smysl.

„Zlom mezi vládou tradice a modernity nastal v (jistě pomyslném) bodě, ve kterém se jistota kontinuity transformovala do vize změny představené jako pokrok;“ v současnosti však dochází k dezintegraci i tohoto mýtu [Hervieu-Léger 2000 (1993): 164]. Zkušenost druhé světové války, zbraní hromadného ničení, odhalení hrůz nacismu a stalinismu nebo objevení jiných kultur znamenaly nový převrat. Dějiny nevedou ke zlatému věku a ideálnímu světu; anebo pokud ano, tak velkými oklikami [Le Goff 2007 (1986): 19]. Kolektivní mýty a utopie modernity ztrácejí pomalu na síle. Zvláště od 60. let 20. století se západní myšlení mění, nejprve v minoritních a alternativních úsecích společnosti, od 80. let pak ve společnosti majoritní. Podle Hervieu-Légerové jsou však pamět a utopie inherentně přítomny i v postmoderní společnosti. Nepřehledná změna a nejistota totiž paradoxně vždy znovu a znovu vyvolávají pamět: „Reference k minulosti už neposkytují systém významů, který by přinášel vysvětlení nedokonalostí světa a nesoudržnosti 
zkušenosti, ani nepředkládají žádný scénář budoucnosti [Hervieu-Léger 2000 (1993): 141-142]. “ Člověk se pak přimyká k novým mýtům, ideologiím či novým náboženským směrům a navrací se k Norovým místům paměti.

Tyto náhledy, v nichž si Nora a Hervieu-Légerová přizvukují, nicméně nejsou nové. Vliv Halbwachse je tu zřejmý. Ten trval na tom, že ačkoli se svět „o sobě“ i světy „společenské“ neustále mění, lidé a skupiny mají tendenci tyto změny eliminovat a vytvářet světy co nejstabilnější, nejtrvalejší a nejznámější - tedy nejjistější. Společnost, a ta náboženská zvláště, se snaží zpomalovat a znehybňovat čas, který neúprosně běží, a tak dosáhnout stability a kontinuity [Halbwachs 2009 (1950): 223]. Ve stejné době - ve 40. letech 20. století - se otázkou smyslu a utrpení v dějinách zabýval např́iklad proslulý rumunský religionista Mircea Eliade. Domníval se, že i současný člověk, který si zakládá na své svobodě a vládě nad historií, bude mít tendenci čas znovu rušit tak, jak to činil člověk archaický, jenž se pravidelně navracel do času mytických počátků: „Můžeme právem předvídat, že čím bude hrůza z dějin větší, čím bude existence vlivem dějin nejistější, tím bude prestiž historicismu menší [Eliade 1993 (1949): 97]. “ Problematika navíc zapadá do obecnější antropologické a sociologické diskuse o detradicionalismu odehrávající se v dichotomiích uzavřenosti, nutnosti, bezpečí, jistoty versus otevřenosti, volby, risku a nejistoty [Heelas - Lash - Morris 1996].

Opouštění a proměna tradice s sebou nesou jak možnosti a výzvy, tak i ohrožení. ${ }^{6}$ Ostatně krize a nejistota občas vedly k milenaristickým hnutím také před nástupem moderny a postmoderny. Vzpomeňme jen na husitství a další reformace a protireformace. Utopie se dovolává změny, odvolává se však jen na jinou tradici, jež je opakem neblahé současnosti (reformace vzhlížela k biblickým časům, renesance k antice): „Utopie slouží k vytvoření alternativní představované kontinuity novým způsobem [Hervieu-Léger 2000 (1993): 144-145].“ Novátorský dnešek vzniká znovuobjevením dávného, budoucnost je tak trochu návratem do minulosti.

\section{Svatojakubská kolektivní pamět}

Pohled na křestanské poutnictví, jaký předkládám v této studii, je velmi úzký a specializovaný. Budu-li poutnictví chápat jako instituci tvořící a vyjadřující kolektivní pamět, která je vtělována do itineráře poutníka a jež je napájena silou minulosti, neznamená to, že je to její nejdůležitější nebo dokonce jediná dimenze. Naopak. Psychosociálních kontextů, ve kterých se poutnictví pohybuje, je celá řada a antropologie poutnictví se mnohým z nich intenzivně věnuje. Dnešní antropologové diskurs kolektivní paměti nevyužívají jen v rámci klasických náboženských poutí, ale třeba též při studiu hledání kořenů [Mitchell 2004] nebo léčby historického traumatu [Dubisch 2004].

To, že se poutnictvím zabýval mimo jiné Halbwachs, ví mimo Francii jen málo antropologů. Přitom v rámci dokazování sociální podmíněnosti paměti využil rovněž poutní tradice do Jeruzaléma [Halbwachs 1992 (1942)]. Ve své Legendární topografii

6 Oživování řetězců paměti jsme svědky např. na Balkáně, v Severním Irsku, Polsku či muslimském světě, kde kráčí politika, nacionalismus a náboženství tradičně ruku v ruce. Milenarismus můžeme vidět na národní a celospolečenské úrovni na příkladě amerického mytologického souboje dobra se zlem, který se manifestoval do hrdinného boje s komunismem a po pádu Sovětského svazu do podobně úporného střetu s islámem a arabským světem. Na individuální úrovni lze milenarismus spatřit v některých typech postmoderní spirituality stejně jako v letničních a jim podobných církvích a sektách. 
evangelií ve Svaté zemi ukazuje, jak se události a místa s nimi spjatá v průběhu dějin měnily podle dobových představ. To, co a kde prožil Ježíšs, nemusí odpovídat tomu, jak věc tradovala raná křestanská církev, jak středověká nebo jak novověká. Ačkoliv byl Jeruzalém mnohokrát pobořen a přestavěn, projektovali si do něho poutníci své představy a ideály. Konkrétní místa připomínají a ztělesňují domnělé minulé události. Tím zpětně ospravedlňují a legitimizují představy, které si poutník přináší: „Je pravda, že křestanské učení je historie; ale její viditelná fakta jsou symboly neviditelných pravd [tamtéž: 224].“ Poutníci v Jeruzalémě dodnes posilují svou víru, stále znovu se snaží učinit pro ně tak významnou minulost představitelnou a hmatatelnou, ačkoliv každé náboženství, každá církev, sekta nebo skupina vidí tuto minulost a její význam jinak [Bowman 1991].

V případě Santiaga de Compostela to není jiné. Stejně jako Jeruzalém je též Santiago „ztělesněnou“ minulostí, „důkazem“ o událostech, které jsou pro věřícího poutníka skutečné a neměnné. Avšak dějiny a význam tohoto místa byly utvářeny po celou dobu jeho existence. Santiago de Compostela patří tradičně spolu s Jeruzalémem a Římem k nejpřednějším poutním místům křestanského světa. Také dnes do něho mírí davy poutníků, často pěšky. ${ }^{7}$ Jeho sláva se odvozuje od ostatků apoštola Jakuba, jež tu mají být uloženy. Jakub Starší (či též Větší), syn Zebedeův, byl dle tradice spolu s Petrem a bratrem Janem nejbližším učedníkem Ježíšovým. ${ }^{8}$ Zemřel jako první z Dvanácti mučednickou smrtí za vlády Heroda Agrippy I. ${ }^{9}$

Tradice vypráví, že Jakub kázal v tehdejší Hispánii, ve Španělsku, nicméně v Bibli ani ve spisech prvotního křestanstva o tom žádná zmínka není. Tuto informaci se dozvídáme až z dokumentu Breviarium apostolorum z 6. nebo 7. století. V 8. století se zmínky o Jakubovi, jakožto misionáři a ochránci Španělska, množí. V Martyrologiu Floruse z Lyonu v revizi Ada z Vienne, pocházejícího z poloviny 9. století, se můžeme dočíst o přenesení Jakubových ostatků (translatio) do nejvzdálenějšího kouta Španělska, k Britskému moři, tedy do Galicie. Na počátku 9. století měl být hrob znovuobjeven (inventio) místními pasáčky (nebo také poustevníkem Pelagiem) podle nebeských znamení. ${ }^{10}$ Biskup Theodemir z Iria Flavia a asturský král Alfonso II. na daném místě nechali vystavět poutní kapli. Během 9. století přešly tyto legendy v širokou známost a kult sv. Jakuba se počal úspěšně rozvíjet. Není zřejmé, kdy a jak přesně toto pojetí svatojakubských dějin vzniklo. Stejně tak není jasné, zda apoštol ve Španělsku vůbec kdy kázal nebo v něm byl dokonce pohřben [Melczer 1993: 7-23].

Nebyly to jen náboženské důvody, které vedly k vytvoření poutního místa a kolektivní paměti s ním spjaté. Poté, co muslimové po roce 711 dobyli téměř celý Pyrenejský poloostrov, zůstala nezávislá pouze hornatá Asturie, která pomalu soustředovala odbojné Vizigóty a další křestany. Asturští panovníci si byli jistě dobře vědomi politického významu objevu Jakubova hrobu: stal se symbolem boje proti muslimům, znovudobývání

7 Výběr svatojakubské pouti jako příkladu se zakládá na mých terénních výzkumech z let 2006 a 2007; zkušenost cesty do Compostely byla předmětem mé postupové práce. V této studii se držím jasně vymezeného teoretického problému, etnografie je tak zatlačena do pozadí. Svatojakubským poutním diskursům a jejich proměně v čase se nicméně věnuji na jiném místě [Kapusta 2011], odkázat lze i na další české práce [např. Vrbová 2006; Lebedová 2008], ze zahraniční produkce bych vyzdvihl knihu Nancy Freyové [1998].

$8 \quad$ Bible Mk 5,37; 9,2; 14,33.

9 Bible Sk 12,2.

10 Možná etymologie názvu Compostela odkazuje právě ke campus stellae, hvězdnému poli. 
a rechristianizace země. Španělská půda je nyní posvěcena a náleží křestanům. Santiago stojí při křestanských vojscích: roku 844 měl asturský král Ramiro I. v bitvě u Clavija porazit Maury za přispění sv. Jakuba. Ten se zde zjevuje na bílém koni s mečem jako Matamoros - Maurobijec. Podobná legenda se vypráví také o bitvě u Las Navas de Tolosa z roku 1212. Reconquistě napomáhali i další bojovníci a dobrodruzi, především z francké říše. A právě v souvislosti se španělsko-francouzskou politikou je svatojakubská kolektivní pamět znovu obohacena. Objevuje se totiž nový objevitel zapomenutého místa Jakubova posledního odpočinku, Karel Veliký. Ten podle legendy zahlédl na nebi hvězdnou cestu (Mléčnou dráhu) směřující do Galicie. Zjevil se mu sám sv. Jakub, jenž mu řekl o jeho vyvolení projet touto cestou a osvobodit zapomenutý hrob z rukou muslimů. Zvěstoval také, že tam pak budou putovat mnohé národy, aby došly odpuštění hříchů a aby chválily Boha. Alespoň tak o věci informuje čtvrtá kniha Codexu Calixtinus (Turpini Historia Caroli Magni et Rolandi) z 12. století. ${ }^{11}$ Podobně se můžeme dočíst o hrdinských skutcích slavného Rolanda, jenž padl poblíž poutní cesty u pyrenejského městečka Roncesvalles. Historicky relevantní důkaz, že Karel Veliký skutečně dorazil až do Galicie, neexistuje. Legenda se vtělila do kolektivní paměti poutníků, kteří si dodnes u Roncesvalles prohlížejí Rolandovy stopy.

Ani skutečnost, že dva nejvýznamnější spisy věnující se svatojakubské tradici - totiž Historia compostelana a již zmíněný Codex Calixtinus, vlastně Liber Sancti Jacobi - pocházejí z 12. století, není náhodná. Úzké rodinné, ekonomické, politické a náboženské vztahy mezi Španělskem a Francií trvaly i nadále. Došlo k masivní christianizační činnosti, jež vycházela z vlivného benediktinského kláštera v Cluny. Podél poutní cesty do Santiaga vznikaly kláštery, jakési „osy stability“ křestaanské kultury, s nimi i obce, města, cesty, mosty atd. Šlo o jeden velký nábožensko-politicko-ekonomický projekt, který měl za úkol osídlit, zkulturnit a ovládnout španělské země. Kult sv. Jakuba a daná kolektivní pamět byly nedílnou součástí tohoto procesu. Ze Santiaga měl být vytvořen „druhý Řím“, což se ve 12. století arcibiskupu Diegu Gelmírezovi skutečně podařilo [Melczer 1993: 7-23].

Dějiny tak, jak byly utvářeny duchovními, politiky i prostým lidem, byly vtiskávány do ústních podání, textů, maleb, předmětů, staveb, míst apod. Netýkaly se jen sv. Jakuba, ale, jak jsme viděli, i Karla Velikého nebo Rolanda, také však dalších postav. Patří mezi ně třeba Bohu oddaný rolník, jenž se vydal za bouře na mši do horského kostelíka na O Cebreiro, kde se stal svědkem zázraku skutečné proměny těla a krve Páně. Nebo také poutník v Santo Domingu de la Calzada, jenž se nevzdal víry a poslušnosti, byl nespravedlivě odsouzen k oběšení, sv. Jakub ho však včas zachránil. Pro obyčejné poutníky byl Jakub mužem v prostém poutnickém oděvu, s holí, brašnou a mušlí, jenž při nich stál.

Souhra společenských, náboženských, ekonomických a politických okolností formuje minulost dle představ a potřeb daných jedinců a skupin. Kde a kdy sv. Jakub působil a byl pohřben, kdy a kdo jeho hrob nalezl, závisí na určité historické či sociální situaci. Kdo vlastně Jakub je, vlastně jak se ve světě zjevuje a jak je zobrazován? Jako apoštol a misionář sloužící Judeji nebo Španělsku? Jako bojovník na koni s mečem sloužící reconquistě? Jako poutník s holí a pláštěm sloužící bohabojným poutníkům?

11 V českém prostředí je př́běh znám ze Zlaté legendy, z kapitoly „Historie Karla Velikého“ [De Voragine - Vidmanová 1998: 378-383]. 
Jedno místo, jedna cesta a jedna postava mohou sloužit všem těmto a mnoha dalším pohledům na minulost. Relikvie, katedrála, kdejaké místo, předmět či obraz na svatojakubské cestě mohou připomínat, oživovat, materializovat (zároveň legitimizovat) minulost, jak je zrovna danou skupinou viděna a přijímána. ${ }^{12}$

\section{Performance, návrat $k$ počátkům a navázání se na řetězec tradice}

Nyní bychom se mohli ponořit do procesu kolektivní paměti a sledovat, jak konkrétně je při rituálu pouti do Compostely připomínána, materializována, prožívána a zvnitřňována. To by však předpokládalo obsáhlý popis a rozbor cesty samé, pro něž tu není prostor. Na tomto místě mě proto bude zajímat jen to, jaký význam mají výše popsané sociálně konstruované dějiny.

Halbwachs při výkladu procesu, jak se dávné představy a praktiky stávají aktuálními i v současnosti, vytváří pomyslnou dichotomii „teologické“ a „mystické“ paměti. Teologům i mystikům přitom jde o jedno: navrátit se k zakládajícím počátkům, poznat, jak to tenkrát bylo. První tak činí teoreticky, druzí prakticky, prožíváním, „jakoby pak bylo možné př́imo dosáhnout události nebo posvátné osoby, které svátost připomíná“ [Halbwachs 1992 (1925): 118]. Také katolický poutník kráčí ve stopách sv. Jakuba a potažmo i Ježíše, pokouší se jim prostřednictvím pouti a rituálů přiblížit a profitovat z jejich blízkosti. Rituály pouti stejně jako pěší cesta sama jsou tělesnými praktikami, které se musí provést, mají-li mít účinek: „Rituál nejsou noviny nebo memoár. Jeho hlavní sdělení je více než vyprávěný a zrcadlící se příběh; je to zahraný akt [Connerton 1989: 70].“

Právě v performanci, v přehrávání úkonů prototypických vzorů se zjevuje síla minulosti. Odkaz k ceněným zakládajícím postavám a událostem poutníkovo konání posvěcuje. Halbwachsovu myšlenku, že minulost může legitimizovat víru či tradici (kolektivní pamět v nejširším slova smyslu), rozvíjí Hervieu-Légerová. Věření je pro ni napojení se na řetězec tradice, nejen na její konkrétní obsah, ale i na její samotný proces, na linii spojující předky a potomky. Jak víme, je to především rituál, který slouží anamnésis, rozpomínání. Další roli hrají náboženští specialisté a jejich „rozpoznaná schopnost vykládat pravdivou pamět skupiny, jež tvoří jádro náboženské síly“ [Hervieu-Léger 2000 (1993): 126]. Na své cestě si poutník dle kolektivní paměti utváří symbolickou krajinu míst, staveb a předmětů a vykonává různé symbolické úkony. Tím vším se navazuje na řetězec tradice, jenž ho spojuje s jejími svatými zakladateli a také s poutníky, kteří činili to samé před ním a budou tak činit i po něm.

\section{Vtělení navrácené minulosti}

Je ale modernímu poutníku takováto víra v kontinuitu linie věřících ještě vlastní? Právě realita současné svatojakubské cesty ukazuje, že nikoliv. Náboženský význam sv. Jakuba a jeho ostatků není v dnešní pouti nejdůležitější, její popularita však neklesá, naopak strmě stoupá. ${ }^{13}$ Výše popsaná kolektivní pamět duši moderního člověka neoslovuje, jaká minulost tedy vlévá do žil svatojakubského fenoménu sílu?

12 Na to, jak se kolektivní paměti skupin otiskují v materiálním světě, kladl Halbwachs velký důraz: „Podoby předmětů, jež nás obklopují, skutečně nesou takový význam. Nikoli neprávem jsme řekli, že nás doprovázejí jako mlčenlivá, nehybná společnost. Nemluví, my jim však rozumíme, protože mají důvěrný smysl, který dokážeme číst [Halbwachs 2009 (1950): 187].“

13 Svatojakubská cesta došla od 80. let 20. století významného přeznačení, odpovídajícímu postmoderní spiritualitě [viz napr. Frey 1998]. 
Porovnejme náš př́ípad s jiným tradičním poutním místem, Walsinghamem, kterému se věnuje významný britský antropolog poutnictví Simon Coleman. Pro věřící je návštěva „anglického Nazaretu“, jak se městečku díky zdejší replice místa Ježíšova narození říká, př́ležitostí dotknout se skrze mimésis, nápodobu, biblické doby a míst. Materializuje se zde kolektivní pamět sahající k počátkům křestanství, ale prostřednictvím tradičních staveb či rituálů také řetězec víry vedoucí až do středověku. Walsingham vyjadřuje a posiluje křestanskou pamět a identitu. Místo však navštěvují i poutníci, jimž křestanská kolektivní pamět mnoho neříká. Etnografický výzkum ukázal, že Walsingham ztělesňuje také národní pamět a identitu, respektive středověký, neporušený anglický venkov, „starou dobrou Anglii“. Tyto své představy návštěvníci vtělují do ulic a staveb městečka, stejně jako okolní krajiny; vykročí tak ze shonu moderní doby a oddají se romantickému, nostalgickému návratu do „skutečného“ světa svých předků. Jakkoliv se mohou představy návštěvníků Walsinghamu odlišovat, sjednocuje je odkaz ke kýžené minulosti, zvláště té středověké. Dějiny církevní, národní, místní i osobní se prolínají a spolupracují. Spojuje je Walsingham, jenž je symbolem kontinuity a stálosti, který je obdařen mocí pramenící z jeho vztahu k minulosti [Coleman 2004].

Podobný proces lze sledovat rovněž v případě Santiaga. Oživení poutní cesty a návštěvnosti města jde ruku v ruce s oživením zájmu o tradici a kulturní dědictví, kterým trasa a město disponují. Ostatně jednou z nejčastějších motivací, k níž se poutníci hlásí, je „historicko-kulturní poznání“. Poutníci navštěvují starobylé kláštery, kostely, muzea, nechávají se pohltit atmosférou archaického španělského venkova, stejně jako starodávnými uličkami rázovitých španělských měst. Historie na poutníka „dýchá“ ze všech stran a poutník, přicházející z hektického moderního světa, jejímu kouzlu v nostalgii podléhá.

Fenoménu se ujala též galicijská vláda a reprezentace města. Sharon Rosemanová si povšimla, že kulturní politika, se kterou se setkáváme v současnosti, není nepodobná té středověké [Roseman 2004]. Santiago si je dobře vědomo svého kulturně-historického kapitálu a chce ho zúročit. V roce 1984 bylo zapsáno na seznam světového kulturního dědictví UNESCO, v roce 1993 došlo i na samotnou svatojakubskou cestu. O dva roky později bylo Evropskou unií zvoleno Evropským hlavním městem kultury roku 2000. ${ }^{14}$ O stř̌edověkých snahách učinit ze Santiaga „druhý Řím“ bylo již pojednáno. V obou případech se osobnosti vytvářející politickou, společenskou a kulturní prestiž města dovolávají jak předních evropských institucí a autorit (ał již Cluny či papežství ve středověku, nebo Bruselu a UNESCO v současnosti), tak mas lidí (at’ již poutníků, nebo turistů), z nichž zpětně plyne zisk a sláva.

Diskurs, v němž se pohybují reprezentanti města, je pro naši dobu příznačný. Santiago de Compostela a svatojakubská cesta se zásadní měrou podílely na utváření evropské historie, kultury a identity. Idea evropské jednoty v pluralismu a toleranci je analogická k ideálu společenství poutníků. Jak už ř́kal Goethe: „Evropa se zrodila na svatojakubské cestě. “ Pro politiky, obyvatele Santiaga a jeho návštěvníky už není křestanská kolektivní pamět spjatá se skutky a zázraky sv. Jakuba atraktivní. Sv. Jakub má v nové „sekulární“ kolektivní paměti místo jen do té míry, do jaké přispěl k historii, kultuře

14 Po boku Santiaga de Compostela stály v roce 2000 Avignon, Bergen, Boloňa, Brusel, Helsinki, Krakov, Praha a Reykjavík. 
a identitě Evropy. Přes obsahovou rozdílnost obou pamětí však lze nalézt jeden společný bod: oba výklady se odvolávají na minulost, která jejich pohled valorizuje a legitimizuje. Dnešní poutníci kráčejí ve stopách těch středověkých, „autentických“, procházejí „původní“ krajinou, kláštery a kostely, starobylou cestou, která ztělesňuje jejich ideály minulosti, jež jsou do cesty vtělovány. Lze si položit otázku, do jaké míry je z tohoto psychosociálního hlediska odlišný návrat do minulosti tradičního věřícího poutníka a toho moderního, sekulárního. Oba vykonávají jakousi mytologickou cestu starých hrdinů navracejících se k myšleným počátkům. Oba vstupují do náboženské kolektivní paměti.

\section{Př́ítomnost minulosti}

Zdá se, že moc minulosti svatojakubskou cestu neopustila, spíše se transformovala do jiné podoby. Minulost má své významné místo i ve světě, jenž se od náboženství distancuje. Vize spásonosné rekonstrukce dějin neopouští ani duši moderního člověka; zapomínání indikuje vzpomínání, matná historie podléhá kouzlu dějinného vyprávění. Co nám tyto závěry exkursu do antropologie poutnictví mohou říci o současném oslnění pamětí? Teze Hervieu-Légerové, že náboženství je řetězec paměti, nebo že je to tradice (kultura?), je banální. Tato sociologická redukce je nicméně v kontextu, ve kterém ji provádí, nebanálním heuristickým nástrojem, přinejmenším z pohledu teorie sekularizace. To, že je teorie dezintegrace a amnézie - rozpadu tradice a ztráty paměti - posunuta do centra studia současné společnosti a náboženství, je odpovědí na neutuchající moc minulosti.

Při četbě prací Hervieu-Légerové a Nory - přes jejich nepochybnou intelektuální brilantnost - se nelze zbavit dojmu, že máme co do činění s eliadovskou nostalgií a romantizací minulosti. Přestože problém neteologizují, i zde jakoby zaznívala lamentace nad tím, že „proces desakralizace lidské existence vyústil nejednou v hybridní formy nízké magie a opičího náboženství“ [Eliade 2006 (1957): 136]. Zvláště Nora se eliadovské dichotomii archetypální a historické koncepce dějin výrazně blíží, přestože - jak se domnívám - nejsou jejich hranice jistě tak ostré. Je ovšem nepochybné, že fenomén amnézie nebo jednoduše detradicionalizace $\mathrm{v}$ dnešním světě existuje. Zároveň ale vidíme tendence k návratu jistých utopií; čím více jsou sociální a náboženské světy a jistoty relativizovány a vytlačovány, tím více se spod krunýře „objektivity“ a „racionality“ probíjejí zpět na povrch. Často pak nacházejí legitimitu v minulosti, která má neustále velkou psychosociální moc ospravedlňovat ideje, přesvědčovat jednotlivce i mobilizovat masy lidí. Někteří autoři - Hervieu-Légerová zvlášt - dokázali tento jev rozpoznat v době, kdy je vskutku aktuální.

Přítomnost minulosti lze spatřit leckde: v „retro“ nebo „etno“ módě, o které mluvil Le Goff; v pídění se po rodokmenech, masovém čtení historických románů či zalíbení ve starožitnostech, o nichž psal Nora; v grandiózním návratu mýtu například v podobě Pána prstenů nebo Harryho Pottera, jak Eliade a ještě před ním Jung předvídali; v hledání kořenů, jehož studiu se věnují někteří antropologové; v návratu instituce poutnictví, ale i v cestovatelství a turismu, pátrajících po exotické minulosti a autentičnosti, jak jsem se snažil předvést v této práci; a tak dále a tak podobně. Nejde jen o „nevinné kratochvíle“ současného člověka, ale o politicky závažnou věc. To, že se některé utopie vyčerpaly, neznamená, že nevznikají nové. Rašení staronových kolektivních představ nacionalismu, xenofobie a rasismu tváří v tvář otázce menšin, přistěhovalců nebo muslimského 
a čínského světa, stejně jako čerstvé ideologie typu ekologismu či genderismu, nesvědčí o tom, že by se člověk stal méně náboženským a mýtotvorným. Možná, že postmoderní doba není „koncem dějin“.

\section{Závěr}

Předložená studie měla řadu rovin. Šlo mi o to kriticky zhodnotit teorii paměti v sociálních vědách vůbec a v antropologii zvláště. Načrtnout její hlavní postavy, směry a témata, ale také odkrýt cesty, kterými se ubírala, promyslet a zproblematizovat její výsledky. Celou prací se ale vine rovněž otázka po smyslu paměti, vlastně minulosti vůbec. Na případu svatojakubské cesty jsem chtěl předvést, jaký význam má minulost nejen pro tradiční, ale i pro moderní poutníky. V rozboru společenskovědních teorií jsem pak poukázal na to, jakou sílu má minulost v myslích intelektuálů, stejně jako ve společnosti obecně. Jakkoli se může zdát, že současný volnomyšlenkářský svět tradici netematizuje a nepotřebuje, ve všech zmíněných příkladech se setkáváme s opakem. Psychosociální moc minulosti v lidském myšlení dosud neřekla své poslední slovo. Sledoval jsem kolektivně utvářenou pamět a minulost obestřenou aurou posvátna: jejich vtělení do svatojakubské cesty i společenskovědního diskursu.

Jak řečeno, věda začala být citlivá $\mathrm{k}$ problematice paměti a tradice na přelomu 80. a 90. let. V této době vycházejí reedice Halbwachsova díla, které velice rychle nabírají na popularitě i mimo frankofonní oblast. V letech 1984-1992 vydává na poli historie Nora svá ambiciózní Místa paměti, dále v roce 1989 se objevuje klasický antropologický text Connertonův, konečně pak následuje sociologický bestseller Hervieu-Légerové z roku 1993. Tyto „manifesty“ tradice a kontinuity nepřišly s ničím radikálně novým či objevným. Byly ale vhodně napsány a přišly ve vhodný čas. Právě společenské klima jim př́lo. Někteří se probudili z postmoderního opojení a odklonili se od dynamismu a procesualismu, které převládaly v 60. až 80. letech. Tak Connerton vyjadřuje své stanovisko jasně: „Zatímco jsou některé dominantní trendy současné sociální teorie často kritizovány za to, že se nezabývají, nebo se zabývají málo, skutečností sociální změny, já se budu snažit vyzdvihnout to, v čem jsou často takové teorie defektní, protože jsou neschopné se adekvátně zabývat skutečností sociálního trvání [Connerton 1989: 39-40].“

To, že sociální vědy daly znovu do pohybu váhy kontinuity a změny, svědčí o tom, že toto dilema je věčné. A není věčné jen v rámci vědy, nýbrž společnosti obecně. Nyní můžeme konstatovat boom paměti a tradice taktéž u nás. Bylo pozoruhodné sledovat, jak o sobě tato skutečnost dávala vědět jen během práce na této studii. Nejenže zrovna vyšel český překlad kritického vydání Halbwachsovy Kolektivní paměti [Halbwachs 2009 (1950)], nýbrž také překlad Výjimečného př́padu Evropy známé britské socioložky Grace Davieové zdůrazňující sílu jistot tradičních historických církví [Davie 2009 (2002)], ${ }^{15}$ ba dokonce se objevila původní česká teoretická práce na téma jistoty a důvěry v současné společnosti sociologa Jana Kellera [Keller 2009]. K tisku se připravovala také rozsáhlá př́padová studie Barbory Spalové, která je ukotvena v teorii kolektivní paměti a jež se zabývá konstruováním pamětí v rámci současné křestanské religiozity v severních Čechách [Spalová 2008].

15 Davieová, inspirována svou souputnicí Hervieu-Légerovou, už ve své dřívější knize pojímá evropské křest̉anské církve jako užitečné studnice tradice a paměti [Davie 2000]. 
Nedávno spatřila světlo českého světa - díky překladu - slavná kniha amerického teoretika nacionalismu Benedicta Andersona. Za pozornost nestojí jen proto, že u nás vychází právě v této době, ale i to, že její poslední kapitola „Pamět a zapomínání“ byla do knihy, pocházející z roku 1983, včleněna až v novém vydání z roku 1991. Dokládá tak, že ani politologie nebyla vưči zmíněnému „pamětí oplodněnému“ období imunní. Anderson ukazuje, že je to identita (př́běh) jedince i národa, ,již je nutné vyprávět, nebot’ si ji nelze zapamatovat“ [Anderson 2008 (1991): 218]. Př́běh, jenž o nás naše rodina nebo národ vypráví, potřebujeme, nebot určuje naše místo ve světě. Mnozí lidé se budou zřejmě nadále přimykat $\mathrm{k}$ různým pamětovým a náboženským řetězcům, mýtům a utopiím, protože otázka po významu, smyslu a identitě je člověku osudem. 


\section{Literatura}

Anderson, Benedict. [2008 (1991)]. Představy společenství: Úvahy o původu a šírení nacionalismu. Praha: Nakladatelství Karolinum.

Assmann, Jan. [1995]. Collective Memory and Cultural Identity. New German Critique 65, s. $125-133$.

Bastide, Roger. [1970]. Mémoire collective et sociologie du bricolage. L'Année sociologique 21, s. $65-108$.

Beisaw, April M. [2010]. Memory, Identity, and NAGPRA in the Northeastern United States. American Anthropologist 112, 2, s. 244-256.

Berger, Peter L. - Luckmann, Thomas. [2001 (1966)]. Sociální konstrukce reality: Pojednání o sociologii vědění. Praha: Centrum pro studium demokracie a kultury.

Berliner, David. [2005]. The Abuses of Memory: Reflections on the Memory Boom in Anthropology. Anthropological Quarterly 78, 1, s. 197-211.

Bloch, Marc. [1939-1940]. La société feódale I.- II. Paris: Albin Michel.

Bowman, Glenn. [1991]. Christian Ideology and the Image of a Holy Land: The Place of Jerusalem Pilgrimage in the Various Christianities. In. Eade, John - Sallnow, Michael J. (eds.). Contesting the Sacred: The Anthropology of Christian Pilgrimage. London - New York: Routledge, s. 99-121.

Burke, Peter. [1989]. History as Social Memory. In. Butler, Thomas (ed.). History, Culture, and the Mind. New York: Basil Blackwell, s. 97-113.

Burke, Peter. [2007 (2000)]. Společnost a vědění: Od Gutenberga k Diderotovi. Praha: Nakladatelství Karolinum.

Candau, Joël. [1998]. Mémoire et identité. Paris: Presses Universitaires de France.

Coleman, Simon. [2004]. Pilgrimage to "England's Nazareth": Landscapes of Myth and Memory at Walsingham. In. Badone, Ellen - Roseman, Sharon R. (eds.). Intersecting Journeys: The Anthropology of Pilgrimage and Tourism. Urbana - Chicago: University of Illinois Press, s. 52-67.

Connerton, Paul. [1989]. How Societies Remember. Cambridge: Cambridge University Press.

Davie, Grace. [2000]. Religion in Modern Europe: A Memory Mutates. Oxford - New York: Oxford University Press.

Davie, Grace. [2009 (2002)]. Výjimečný př́pad Evropa: Podoby víry v dnešním světě. Brno: Centrum pro studium demokracie a kultury.

Dubisch, Jill. [2004]. Heartland of America: Memory, Motion and the (Re)construction of History on a Motorcycle Pilgrimage. In. Coleman, Simon - Eade, John (eds.). Reframing Pilgrimage: Cultures in Motion. London - New York: Routledge, s. 105-132.

Ebron, Paulla A. [1998]. Enchanted Memories of Regional Difference in African American Culture. American Anthropologist 100, 1, s. 94-105.

Eliade, Mircea. [1993 (1949)]. Mýtus o věčném návratu. Praha: Oikoymenh.

Eliade, Mircea. [2006 (1957)]. Posvátné a profánní. Praha: Oikoymenh.

Frey, Nancy Louise. [1998]. Pilgrim Stories: On and Off the Road to Santiago. Berkeley - Los Angeles - London: University of California Press.

Gedi, Noa - Elam, Yigal. [1996]. Collective Memory - What is It? History and Memory 8, 2, s. $30-50$.

Goody, Jack. [1972]. The Myth of the Bagre. Oxford: Clarendon Press.

Goody, Jack. [1977]. The Domestication of the Savage Mind. Cambridge: Cambridge University Press.

Halbwachs, Maurice. [1992 (1925)]. The Social Frameworks of Memory. In. Halbwachs, Maurice - Coser, Lewis A. On Collective Memory. Chicago - London: The University of Chicago Press, s. $35-190$.

Halbwachs, Maurice. [1992 (1942)]. The Legendary Topography of the Gospels in the Holy Land. In. Halbwachs, Maurice - Coser, Lewis A.: On Collective Memory. Chicago - London: The University of Chicago Press, s. 191-236. 
Halbwachs, Maurice. [2009 (1950)]. Kolektivní pamět. Praha: Sociologické nakladatelství (SLON).

Heelas, Paul - Lash, Scott - Morris, Paul (eds.). [1996]. Detraditionalization: Critical Reflections on Authority and Identity. Cambridge - Oxford: Blackwell Publishers.

Hervieu-Léger, Danièle. [1990]. Religion and Modernity in the French Context: For a New Approach to Secularization. Sociological Analysis 51, s. 15-25.

Hervieu-Léger, Danièle. [2000 (1993)]. Religion as a Chain of Memory. New Brunswick: Rutgers University Press.

Kansteiner, Wulf. [2002]. Finding Meaning in Memory: A Methodological Critique of Collective Memory Studies. History and Theory 41, 2, s. 179-197.

Kapusta, Jan. [2011]. Odkaz Victora Turnera v současné antropologii poutnictví: Zkušenost pouti do Santiaga de Compostela. Český lid 98, 2, s. 135-153.

Keller, Jan. [2009]. Nejistota a důvěra aneb k čemu je modernitě dobrá tradice. Praha: Sociologické nakladatelství (SLON).

Klein, Kerwin L. [2000]. On the Emergence of Memory in Historical Discourse. Representations 69, s. $127-150$.

Küchler, Susanne. [1988]. Malangan: Objects, Sacrifice and the Production of Memory. American Ethnologist 15, 4, s. 625-637.

Kvasničková, Adela. [2005]. Náboženstvo ako kolektívna pamät: Prípad Slovenska a Čiech. Bratislava: Univerzita Komenského.

Lebedová, Šárka. [2008]. Funkce poutnictví v dějinách evropské kultury. Diplomová práce. Praha: Univerzita Karlova.

Le Goff, Jacques. [2007 (1986)]. Pamět a dějiny. Praha: Argo.

Melczer, William. [1993]. Introduction. In. Melczer, William. The Pilgrim's Guide to Santiago de Compostela. New York: Italica Press, s. 1-82.

Mitchell, Hildi. [2004]. "Being there": British Mormons and the History Trail. In. Coleman, Simon - Eade, John (eds.). Reframing Pilgrimage: Cultures in Motion. London - New York: Routledge, s. 26-44.

Namer, Gérard. [2009 (1997)]. Doslov. In. Halbwachs, Maurice. Kolektivní pamět. Praha: Sociologické nakladatelství (SLON), s. 228-281.

Nešpor, Zdeněk R. [2008]. Náboženství a kolektivní pamět. In. Nešpor, Zdeněk R. - Václavík, David (eds.). Př́ručka sociologie náboženství. Praha: Sociologické nakladatelství (SLON), s. $82-88$.

Nora, Pierre (ed.). [1984-1992]. Les Lieux des mémoire I.-III. Paris: Gallimard.

Nora, Pierre. [1989]. Between Memory and History: Les Lieux de Mémoire. Representations 26, s. 7-25.

Olick, Jeffrey K. [1999]. Collective Memory: The Two Cultures. Sociological Theory 17, 3, s. 333-348.

Olick, Jeffrey K. - Robbins, Joyce. [1998]. Social Memory Studies: From “Collective Memory” to the Historical Sociology of Mnemonic Practices. Annual Review of Sociology 24, s. 105-140.

Roseman, Sharon R. [2004]. Santiago de Compostela in the Year 2000: From Religious Center to European City of Culture. In. Badone, Ellen - Roseman, Sharon R. (eds.). Intersecting Journeys: The Anthropology of Pilgrimage and Tourism. Urbana - Chicago: University of Illinois Press, s. 68-88.

Spalová, Barbora. [2008]. Bůh ví proč: Studie pamětí a režimů moci v křestanských církvích $v$ severních Čechách. Disertační práce. Praha: Univerzita Karlova.

Stoller, Paul. [1994]. Embodying Colonial Memories. American Anthropologist 96, 3, s. 634-648.

Šubrt, Jiří - Pfeiferová, Štěpánka. [2010]. Kolektivní pamět jako předmět historicko-sociologického bádání. Historická sociologie 1/2010, s. 9-29.

Todorov, Tzvetan. [1995]. Les abus de la mémoire. Paris: Arléa.

Vansina, Jan. [1985]. Oral Tradition as History. Madison: University of Wisconsin Press.

De Voragine, Jakub - Vidmanová, Anežka. [1998]. Legenda aurea. Praha: Vyšehrad.

Vrbová, Kateřina. [2006]. Fenomén současného náboženského poutnictví na príkladu pouti do Santiaga de Compostela. Bakalářská práce. Praha: Univerzita Karlova. 
Jan Kapusta (1985) vystudoval etnologii na Filozofické fakultě Univerzity Karlovy v Praze. Na stejném pracovišti pokračuje v doktorandském studiu. V letech 2007-2008 studoval obecnou sociální antropologii a etnologii Latinské Ameriky na Universidad Complutense v Madridu. Prováděl terénní výzkumy ve Španělsku (2006 a 2007) a v Guatemale (2009). Zabývá se antropologii náboženství (poutnictví, obětní rituály) a etnologii Latinské Ameriky (mayská kultura). 